\title{
Perception and Expectation of Tourists Toward the Accommodation Services in Rural Tourism Penglipuran Bangli
}

\author{
Putu Ratih Pertiwi, Putu Diah Kesumadewi, Ida Ayu Trisna Eka Putri
}

Program Studi Diploma IV Pariwisata, Fakultas Pariwisata,Universitas Udayana Denpasar, Indonesia ratihpertiwi@unud.ac.id

\begin{abstract}
This research aims to know the perception and the expectation of tourists toward the accommodation services in Penglipuran Rural Tourism. In the development of rural tourism as an alternative tourism development approach, tourists who are expected to come not only to enjoy the natural beauty and the culture of the community. But also to stay more than a day so that can be directly involved with the culture of the local community, in accordance to the concept of rural tourism. Therefore, accommodation services play such an important role to provide a pleasant stay for the tourists through the facilities dan their services, likewise in Penglipuran Rural Tourism. To discover it, necessary data from several tourists who stayed in accommodation of Penglipuran Rural Tourism used as samples. Analyzed using descriptive qualitative analysis technique where Likert Scale Analysis is needed to determine the perception of the tourists toward the accommodation in Penglipuran Rural Tourism,Importance-Performance Analysis used to determine the expectation of the tourists, and 7Ps of marketing mix used as the indicators. As the result, the perception and the expectation of the tourists toward the accommodation services in Penglipuran Rural Tourism, both of guesthouse and homestay have the average scores as perception $(4,16)$ and expectation $(4,16)$ from 22 indicators of services, it shows that the performance generally in accordance with the tourists' expectation. Based on the priority level, all indicators have the same level of satisfaction (100\%), it means all indicators have the same priority either on guesthouse accommodation services or homestay accommodation services. The suggestion that can be given from this research to the administrator of Penglipuran Rural Tourism is to maintain and improve the service that they deliver to the tourists in order to provide a pleasant stay for them when they are in Penglipuran Rural Tourism.
\end{abstract}

Keyword: Perception, expectation, tourist, accommodation service, rural tourism.

\section{INTRODUCTION}

One of the important factors in meeting the needs while traveling isaccommodation service, it is also as a driving factor of the existence of rural tourism. In the development of rural tourism as an alternative tourism development approach, tourists who are expected to come not only to enjoy the natural beauty and the culture of the community. But also to stay more than a day so that can be directly involved with the culture of the local community, of course, they need a place to sleep, to eat, to drink and all of their basic activities in their tourism destination.

Therefore, the accommodation facilities are needed to be concerned in order to meet the tourists' needs, likewise in Penglipuran Rural Tourism. In developing rural tourism, it needs an affordable accommodation to attract the tourists to come not only for visiting but to attract their interest to stay more than a day, and involve in the local community's traditional activities.

The purpose of this research in to know the perception and the expectation of tourists toward the accommodation services in Penglipuran Rural Tourism. Where the research can use as a reference for the administrator of Penglipuran Rural Tourism in developing their accommodation according to the tourists' response and attract tourists not only to visit but to stay more than a day and joining the traditional activities of the local community in Penglipuran Rural Tourism. 


\section{RESEARCH METHOD}

This research method is descriptive qualitative analysis technique where Likert Scale Analysis is needed to determine the perception of the tourists toward the accommodation service in Penglipuran Rural Tourism and Important Performance Analysis used to determine the expectation of the tourists. Data collection was done through observation, depth interview, and questionnaires. Indicators that used are adopted from 7Ps Marketing Mix by Kotler (2008) such as product, price, place, promotion, physical evidence, people, dan process. It is modified as accommodation facilities and food \& beverage (to represent the product and physical evidence), distribution and location (to represent place), service (to represent process), staff/ individual performance (to represent people), price, adn promotion.

To get an information about perception and expectation of the tourists toward the accommodation in Penglipuran Rural Tourism, the authors conducted a survey of 30 tourists who staying in the accommodation of Penglipuran Rural Tourism (both of guesthouse and homestay) as samples, where in detremining the sample in this research, the authors adopted a boring sampling approach, where all of the total samples are used, since the number of population is relatively small, less than 30 , or a research which has a purpose of a generalization with a small error (Sugiyono, 2007). Considering the low number of tourists who stay in the research location.

\section{RESULT AND ANALYSIS}

As we can see on the Table 1 below, the result shows that the perception and the expectation of the tourists toward the accommodation services in Penglipuran Rural Tourism, both of guesthouse and homestay have the average scores as perception $(4,16)$ and expectation $(4,16)$ from 22 indicators of services, it shows that the performance generally in accordance with the tourists' expectation.

Table 1.

Performance, Importance Assessment, and Appropriate Level of

Accommodation Services in Penglipuran Rural Tourism

\begin{tabular}{llllllll}
\hline No $\quad$ Indicators & Performance & Importance & $X$ & $Y$ & Tki & Category
\end{tabular}

GUESTHOUSE

\begin{tabular}{lllllll}
\hline Accommodation Facilities & & 17 & 4,25 & 4,25 & 100 & Satisfied \\
\hline $1 \quad \begin{array}{l}\text { Coziness, neatness, } \\
\text { cleanliness of the } \\
\text { room }\end{array}$ & 17 & 17 & 4,25 & 4,25 & 100 & Satisfied \\
\hline $2 \quad \begin{array}{l}\text { Coziness, neatness, } \\
\text { cleanliness of other } \\
\text { facilities. }\end{array}$ & 17 & 14 & 3,5 & 3,5 & 100 & \\
\hline $3 \quad \begin{array}{l}\text { Interesting programs } \\
\text { offered by } \\
\text { guesthouse (such as } \\
\text { the local activities) }\end{array}$ & 14 & 17 & 4,25 & 4,25 & 100 & \\
\hline & $\begin{array}{l}\text { A calm ambience } \\
\text { and a beautiful } \\
\text { traditional } \\
\text { architecture }\end{array}$ & 17 & & & & \\
\hline
\end{tabular}

\begin{tabular}{|c|c|c|c|c|c|c|c|}
\hline \multicolumn{8}{|c|}{ Food \&Beverage } \\
\hline 5 & $\begin{array}{l}\text { Variety of food \& } \\
\text { beverage }\end{array}$ & 16 & 16 & 4 & 4 & 100 & Satisfied \\
\hline 6 & $\begin{array}{l}\text { Delicious food \& } \\
\text { beverage }\end{array}$ & 18 & 18 & 4,5 & 4,5 & 100 & Satisfied \\
\hline 7 & $\begin{array}{l}\text { Fresh and hygiene } \\
\text { food \& beverage }\end{array}$ & 18 & 18 & 4,5 & 4,5 & 100 & Satisfied \\
\hline
\end{tabular}




\begin{tabular}{|c|c|c|c|c|c|c|c|}
\hline 8 & $\begin{array}{l}\text { Regular room } \\
\text { cleaning service by } \\
\text { staff including } \\
\text { making the bed and } \\
\text { clean up the } \\
\text { bathroom }\end{array}$ & 19 & 19 & 4,75 & 4,75 & 100 & Satisfied \\
\hline 9 & $\begin{array}{l}\text { Professional and } \\
\text { polite service }\end{array}$ & 19 & 19 & 4,75 & 4,75 & 100 & Satisfied \\
\hline 10 & $\begin{array}{l}\text { Accommodation has } \\
\text { a SOP for the } \\
\text { service (changing } \\
\text { towel regularly, } \\
\text { hygiene and } \\
\text { sanitation }\end{array}$ & 18 & 18 & 4,5 & 4,5 & 100 & Satisfied \\
\hline
\end{tabular}

\begin{tabular}{|c|c|c|c|c|c|c|c|}
\hline \multicolumn{8}{|c|}{ Staff Performance } \\
\hline 11 & Warm welcoming & 18 & 18 & 4,5 & 4,5 & 100 & Satisfied \\
\hline 12 & $\begin{array}{l}\text { Staff has a } \\
\text { willingness to help }\end{array}$ & 18 & 18 & 4,5 & 4,5 & 100 & Satisfied \\
\hline 13 & $\begin{array}{l}\text { How staff dealing } \\
\text { with complaint and } \\
\text { problem }\end{array}$ & 17 & 17 & 4,25 & 4,25 & 100 & Satisfied \\
\hline 14 & $\begin{array}{l}\text { A clear information } \\
\text { provided by staff }\end{array}$ & 15 & 15 & 6,5 & 6,5 & 100 & Satisfied \\
\hline 15 & $\begin{array}{l}\text { Staff speak English } \\
\text { fluently }\end{array}$ & 15 & 15 & 6,5 & 6,5 & 100 & Satisfied \\
\hline
\end{tabular}

\begin{tabular}{|c|c|c|c|c|c|c|c|}
\hline \multicolumn{8}{|c|}{ Price } \\
\hline 16 & $\begin{array}{l}\text { Convenient price as } \\
\text { its product and } \\
\text { service }\end{array}$ & 18 & 18 & 4,5 & 4,5 & 100 & Satisfied \\
\hline \multicolumn{8}{|c|}{ Location and Distribution } \\
\hline 17 & $\begin{array}{l}\text { Location is } \\
\text { accessible }\end{array}$ & 17 & 17 & 4,25 & 4,25 & 100 & Satisfied \\
\hline 18 & $\begin{array}{l}\text { Location is close to } \\
\text { other tourists } \\
\text { attraction }\end{array}$ & 17 & 17 & 4,25 & 4,25 & 100 & Satisfied \\
\hline \multicolumn{8}{|c|}{ Promotion } \\
\hline 19 & $\begin{array}{l}\text { Easy to get the } \\
\text { information of } \\
\text { Penglipuran and its } \\
\text { accommodation }\end{array}$ & 18 & 18 & 4,5 & 4,5 & 100 & Satisfied \\
\hline 20 & $\begin{array}{l}\text { A good testimony of } \\
\text { Penglipuran and its } \\
\text { accommodation by } \\
\text { the tourists }\end{array}$ & 18 & 18 & 4,5 & 4,5 & 100 & Satisfied \\
\hline 21 & $\begin{array}{l}\text { Accommodation } \\
\text { facilities are } \\
\text { compatible with the } \\
\text { promotion }\end{array}$ & 17 & 17 & 4,25 & 4,25 & 100 & Satisfied \\
\hline 22 & $\begin{array}{l}\text { Promotion media } \\
\text { provides a complete } \\
\text { and interesting }\end{array}$ & 16 & 16 & 4 & 4 & 100 & Satisfied \\
\hline
\end{tabular}


information

\section{HOMESTAY}

\begin{tabular}{|c|c|c|c|c|c|c|c|}
\hline \multicolumn{8}{|c|}{ Accommodation Facilities } \\
\hline 1 & $\begin{array}{l}\text { Coziness, neatness, } \\
\text { cleanliness of the } \\
\text { room }\end{array}$ & 112 & 112 & 4,30 & 4,30 & 100 & Satisfied \\
\hline 2 & $\begin{array}{l}\text { Coziness, neatness, } \\
\text { cleanliness of other } \\
\text { facilities }\end{array}$ & 110 & 110 & 4,23 & 4,23 & 100 & Satisfied \\
\hline 3 & $\begin{array}{l}\text { Interesting programs } \\
\text { offered by } \\
\text { guesthouse (such as } \\
\text { the local activities) }\end{array}$ & 86 & 86 & 3,30 & 3,30 & 100 & Satisfied \\
\hline 4 & $\begin{array}{l}\text { A calm ambience } \\
\text { and a beautiful } \\
\text { traditional } \\
\text { architecture }\end{array}$ & 104 & 104 & 4 & 4 & 100 & Satisfied \\
\hline
\end{tabular}

\section{Food \& Beverage}

\begin{tabular}{clcccccc}
\hline 5 & $\begin{array}{l}\text { Variety of food \& } \\
\text { beverage }\end{array}$ & 101 & 101 & 3,88 & 3,88 & 100 & Satisfied \\
\hline 6 & $\begin{array}{l}\text { Delicious food \& } \\
\text { beverage }\end{array}$ & 103 & 103 & 3,96 & 3,96 & 100 & Satisfied \\
\hline 7 & $\begin{array}{l}\text { Fresh and hygiene } \\
\text { food \& beverage }\end{array}$ & 103 & 103 & 3,96 & 3,96 & 100 & Satisfied \\
\hline
\end{tabular}

\section{Service}

\begin{tabular}{|c|c|c|c|c|c|c|c|}
\hline 8 & $\begin{array}{l}\text { Regular room } \\
\text { cleaning service by } \\
\text { staff including } \\
\text { making the bed and } \\
\text { clean up the } \\
\text { bathroom }\end{array}$ & 117 & 117 & 4,5 & 4,5 & 100 & Satisfied \\
\hline 9 & $\begin{array}{l}\text { Professional and } \\
\text { polite service }\end{array}$ & 112 & 112 & 4,30 & 4,30 & 100 & Satisfied \\
\hline 10 & $\begin{array}{l}\text { Accommodation has } \\
\text { a SOP for the } \\
\text { service (changing } \\
\text { towel regularly, } \\
\text { hygiene and } \\
\text { sanitation }\end{array}$ & 102 & 102 & 3,92 & 3,92 & 100 & Satisfied \\
\hline
\end{tabular}

\begin{tabular}{|c|c|c|c|c|c|c|c|}
\hline \multicolumn{8}{|c|}{ Staff Performance } \\
\hline 11 & Warm welcoming & 111 & 111 & 4,26 & 4,26 & 100 & Satisfied \\
\hline 12 & $\begin{array}{l}\text { Staff has a } \\
\text { willingness to help }\end{array}$ & 110 & 110 & 4,23 & 4,23 & 100 & Satisfied \\
\hline 13 & $\begin{array}{l}\text { How staff dealing } \\
\text { with complaint and } \\
\text { problem }\end{array}$ & 102 & 102 & 3,92 & 3,92 & 100 & Satisfied \\
\hline 14 & $\begin{array}{l}\text { A clear information } \\
\text { provided by staff }\end{array}$ & 102 & 102 & 3,92 & 3,92 & 100 & Satisfied \\
\hline
\end{tabular}




\begin{tabular}{|c|c|c|c|c|c|c|c|}
\hline 15 & $\begin{array}{l}\text { Staff speak English } \\
\text { fluently }\end{array}$ & 96 & 96 & 3,69 & 3,69 & 100 & Satisfied \\
\hline \multicolumn{8}{|c|}{ Price } \\
\hline 16 & $\begin{array}{l}\text { Convenient price as } \\
\text { its product and } \\
\text { service }\end{array}$ & 110 & 110 & 4,23 & 4,23 & 100 & Satisfied \\
\hline \multicolumn{8}{|c|}{ Location and Distribution } \\
\hline 17 & $\begin{array}{l}\text { Location is } \\
\text { accessible }\end{array}$ & 112 & 112 & 4,30 & 4,30 & 100 & Satisfied \\
\hline 18 & $\begin{array}{l}\text { Location is close to } \\
\text { other tourists } \\
\text { attraction }\end{array}$ & 109 & 109 & 4,19 & 4,19 & 100 & Satisfied \\
\hline \multicolumn{8}{|c|}{ Promotion } \\
\hline 19 & $\begin{array}{l}\text { Easy to get the } \\
\text { information of } \\
\text { Penglipuran and its } \\
\text { accommodation }\end{array}$ & 105 & 105 & 4,03 & 4,03 & 100 & Satisfied \\
\hline 20 & $\begin{array}{l}\text { A good testimony of } \\
\text { Penglipuran and its } \\
\text { accommodation by } \\
\text { the tourists }\end{array}$ & 107 & 107 & 4,11 & 4,11 & 100 & Satisfied \\
\hline 21 & $\begin{array}{l}\text { Accommodation } \\
\text { facilities are } \\
\text { compatible with the } \\
\text { promotion }\end{array}$ & 98 & 98 & 3,76 & 3,76 & 100 & Satisfied \\
\hline 22 & $\begin{array}{l}\text { Promotion media } \\
\text { provides a complete } \\
\text { and interesting } \\
\text { information. }\end{array}$ & 99 & 99 & 3,80 & 3,80 & 100 & Satisfied \\
\hline \multicolumn{2}{|c|}{ Total } & 2688 & 2688 & 183,04 & 183,04 & 4400 & \multirow{2}{*}{ Satisfied } \\
\hline Ave & & 61,09 & 61,09 & 4,16 & 4,16 & 100 & \\
\hline
\end{tabular}

Source: Result of The Data 2017

The next stage is a mapping between importance and performance both in Penglipuran Rural Tourism Guesthouse and Homestay into Cartesian Diagram Importance-Performance Analysis. It shows on Figure 1(performance in the guesthouse) and Figure 2(performance in the homestay) below, where 22 attributes divided into 4 quadrants.

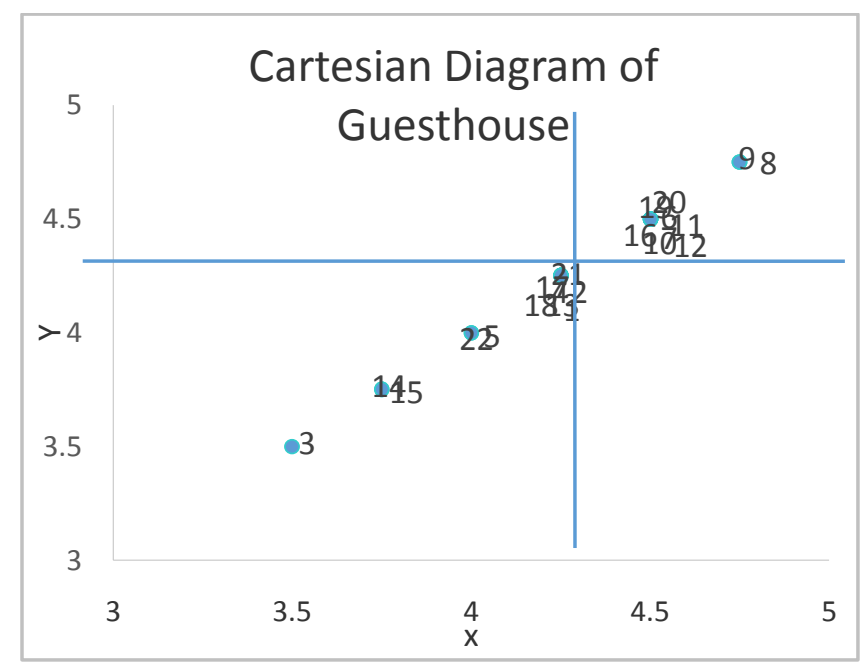

Fig 1. Cartesian Diagram Importance Performance Analysis of Penglipuran Rural Tourism Guesthouse. 
The Cartesian Diagram shows that:

\section{Quadrant A (Concentrate Here)}

In this quadrant shows that there are no attributes, which means the guesthouse has delivered their service very well.

\section{Quadrant B (Keep Up The Good Work)}

In this quadrant shows that there are 10 attributes, which are considered appropriate by tourists who are staying in the guesthouse. These 10 attributes that should be well maintained are:

a. Delicious food \& beverage (6)

b. Fresh and hygiene food \& beverage (7)

c. Regular room cleaning service by staff including making the bed and clean up the bathroom (8)

d. Professional and polite service (9)

e. The accommodation has a SOP for the service (changing towel regularly, hygiene and sanitation (10)

f. Warm welcoming (11)

g. The staff has a willingness to help (12)

h. Convenient price as its product and service (16)

i. Easy to get the information of Penglipuran and its accommodation (19)

j. A good testimony of Penglipuran and its accommodation by the tourists (20)

\section{Quadrant C (Low Priority)}

In this quadrant shows that there are 12 attributes, which are considered not too important for the tourists, and in fact, the performance, is not really special. Performance improvements in these attributes need to be reconsidered since the benefits that felt by the tourists is very small. Those 12 attributes are:

a. Coziness, neatness, cleanliness of the room (1)

b. Coziness, neatness, cleanliness of other facilities (2)

c. Interesting programs offered by guesthouse (such as the local activities) (3)

d. A calm ambiance and a beautiful traditional architecture (4)

e. Variety of food \& beverage (5)

f. How staff dealing with complaint and problem (13)

g. A clear information provided by staff (14)

h. Staff speak English fluently (15)

i. Location is accessible (17)

j. Location is close to other tourists attraction (18)

k. Accommodation facilities are compatible with the promotion (21)

1. Promotion media provides a complete and interesting information (22)

\section{Quadrant D (Possible Overkill)}

In this quadrant means that the attributes are not really important, yet the performance is exaggerating. However, it shows that there is no attribute in this quadrant, which means the guesthouse has delivered their service appropriately.

The next diagram on Picture 3.2 shows the performance of homestay in Penglipuran Rural Tourism.

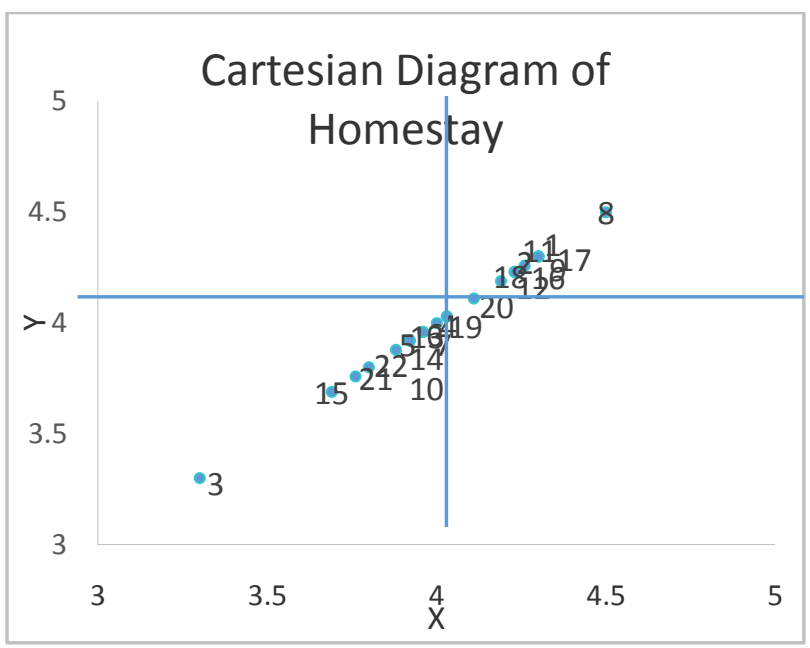

Fig 2. Cartesian Diagram Importance Performance Analysis of Penglipuran Rural Tourism Homestay.

\section{Quadrant A (Concentrate Here)}

In this quadrant shows that there is no attribute, which means the homestay has delivered their service very well.

\section{Quadrant B (Keep Up The Good Work)}

In this quadrant shows that there are 10 attributes, which are considered appropriate by tourists who are staying in the homestay. These 10 attributes that should be well maintained are:

a. Coziness, neatness, cleanliness of the room. (1)

b. Coziness, neatness, cleanliness of other facilities. (2)

c. Regular room cleaning service by staff including making the bed and clean up the bathroom (8)

d. Professional and polite service (9)

e. Warm welcoming (11)

f. The staff has a willingness to help (12)

g. Convenient price as its product and service (16)

h. Location is accessible (17)

i. Location is close to other tourists attraction (18)

j. A good testimony of Penglipuran and its accommodation by the tourists (20)

\section{Quadrant C (Low Priority)}

In this quadrant shows that there are 12 attributes, which are considered not too important for the tourists, and in fact, the performance, is not really special. Performance improvements in these attributes need to be reconsidered since the benefits that felt by the tourists is very small. Those 12 attributes are:

a. Interesting programs offered by guesthouse (such as the local activities (3)

b. A calm ambiance and a beautiful traditional architecture (4)

c. Variety of food \& beverage (5)

d. Delicious food \& beverage (6)

e. Fresh and hygiene food \& beverage (7)

f. The accommodation has a SOP for the service (changing towel regularly, hygiene and sanitation (10) 
g. How staff dealing with complaint and problem (13)

h. A clear information provided by staff (14)

i. Staff speak English fluently (15)

j. Easy to get the information of Penglipuran and its accommodation (19)

k. Accommodation facilities are compatible with the promotion (21)

1. Promotion media provides a complete and interesting information (22)

\section{Quadrant D (Possible Overkill)}

In this quadrant means that the attributes is not really important, yet the performance is exaggerating. However, it shows that there is no attribute in this quadrant, which means the guesthouse, has delivered their service appropriately.

\section{The Level of Tourists Satisfaction Toward The Performance Both of Guesthouse and Homestay In Penglipuran Rural Tourism}

The next stage is to determine the satisfaction customer index, the purpose is to know the level of tourists satisfaction toward the performance both of guesthouse and homestay in Penglipuran Rural Tourism. According to the result of importance-performance rating and the appropriate level (Table 3.1).

a. Satisfaction level toward the performance of guesthouse:

Satisfaction level $=\sum \mathbf{T K i}$

$$
\begin{gathered}
100 \%+100 \%+100 \%+ \\
100 \%+100 \%+ \\
100 \%+100 \%+ \\
\frac{100 \%+100 \%}{22} \\
=\underline{2200 \%}=100 \%
\end{gathered}
$$

\section{$\mathbf{K}$}

$$
=100 \%+100 \%+100 \%+100 \%+
$$$$
100 \%+100 \%+100 \%+100 \%+
$$$$
100 \%+100 \%+100 \%+100 \%+
$$$$
100 \%+100 \%+100 \%+100 \%
$$

22

b. Satisfaction level toward the performance of homestay:

Satisfaction level $=\sum \mathbf{T K i}$

$$
\begin{aligned}
& =100 \%+100 \%+100 \%+100 \%+ \\
& \mathbf{K} \\
& 100 \%+100 \%+100 \%+100 \%+ \\
& 100 \%+100 \%+100 \%+100 \%+ \\
& 100 \%+100 \%+100 \%+100+ \\
& 100 \%+100 \%
\end{aligned}
$$

$$
=\underline{2200 \%}=100 \%
$$

22

It shows the value of the appropriate level in each indicator is $100 \%$. It means generally tourists who are staying in the guesthouse and homestay of Penglipuran Rural Tourism are satisfied toward the performance of the accommodation.

As the value of the satisfaction is $100 \%$ and all of the indicators in both of the guesthouse and homestay performance have the same value, therefore all of the indicators have the same level of priority to be well maintained, in order to keep the good performance in the accommodation.

\section{Rural Tourism in These Present Days}

The issue of the rural tourism development as an alternative tourism has been talked around the world, but in its development, the rural tourism is only a destination visited by tourists in just hours. It denies the concept of rural tourism itself, wherein the development of rural tourism, tourists who come not only to visit for just hours to enjoy the natural beauty and the culture of the community. But more than that they are expected to stay more than a day so that can be directly involved in the culture of the local community. As cited by Inskeep (1991:166) "Village Tourism, where small groups of tourist stay in or near traditional, often remote villages and learn about village life and the local environment".

It could be realized when the destination supported by accommodation services which are in accordance with the expectations of tourists. To support the development of tourism in a destination, it should have attractions, accommodations, accessibility, ancillaries, and community involvement (Inskeep, 1991:39). Also, Nuryanti (1993:2-3) stated that rural tourism is a form of integration among attractions, accommodation, and support facilities, which presented in a structure of community life that integrates with their culture and tradition. Based on those concepts, we know that accommodation service has a very important role in the tourism industry because as in the tourism activities there is a movement of people from their origin to the area of tourist's destination. People who travel certainly need a place to sleep, eat, drink, and other basic activities on their destination.

Penglipuran is one of the rural tourism in Bali who has very high potential. As a pioneer of rural tourism in Bali, this village is one of the tourist destinations in Bali located in DesaKubu, Bangli. The characteristic of this village showed by the traditional architecture of their identical house gate and lined up beautifully along the village. There are some interesting activities offered by Penglipuranthat can be enjoyed by tourists, such as group events (outing, outbound, and gathering), adventure (cycling and camping), and tour. For the tourists who want to experience the traditional atmosphere and interact with local people, Penglipuran offers two kinds of accommodations they are the guesthouse and the traditional homestay who host by 
helocal people. Very unfortunate if this tourist village is not maintained in accordance with the concept of a tourist village completely. Maintaining this village in accordance with the entire concept of rural tourism is such a big challenge in these times.

The existence of Penglipuran Rural Tourism is definitely getting well preserved when the management has real feedback by the tourists toward the performance of accommodation services, relating to facilities, food \& beverage, service, staff/ individual performance, price, and location. Based on the data obtained, tourists who are staying in the accommodation of Penglipuran Rural Tourism either in the guesthouse or the homestay, they do have the expectation toward the performance of the accommodation. The result shows that the value of their satisfaction and the appropriate level between the expectation and the performance of the accommodation is $100 \%$ that means that tourists who are staying in both of the accommodation are satisfied. This feedback can be used as a reference in the further development of their accommodation services in Penglipuran Rural Tourism.

\section{CONCLUSION}

The perception and the expectation of tourists toward the accommodation services in Penglipuran Rural Tourism has value of the appropriate level as much as $100 \%$. It means that generally tourists who are staying in the guesthouse and homestay of Penglipuran Rural Tourism are satisfied and their expectation is appropriate toward the performance of the accommodation.

\section{ACKNOWLEDGMENT}

We thanks to the Rector of Udayana University, The Chairman of LPPM Udayana University, and The Dean of the Faculty of Tourism Udayana University who has provided the opportunity for the team to participate in disseminating the results of research as a form of Tri Dharma PerguruanTinggi.

\section{REFERENCES}

[1] Inskeep Edward. (1991). Tourism Planning An Integrated and Sustainable Development Approach. New York: Van Nostrand Reinhold.

[2] Kotler, Philip; Armstrong, Garry, 2008. PrinsipprinsipPemasaran. Jilid 1. Erlangga. Jakarta.

[3] Nuryanti, W. 1993. DesaWisata: Concept. Perspective and Challenge. Yogyakarta: GadjahMada University Press.

[5] Sharpley, Julia and Richard. 1997. Rural Tourism An Introduction. International Thomson Business Press. London. 